\title{
Struktur Komunitas Bulu Babi Di Perairan Pantai Kampung Baru Pulau Banda Kabupaten Maluku Tengah
}

\author{
Deli Wakano $^{1^{*}}$, Laury Marcia Chara Huwae ${ }^{1}$ \\ ${ }^{1}$ Jurusan Biologi, Fakultas Matematika dan Ilmu Pengetahuan Alam \\ Universitas Pattimura, Ambon \\ *Email: delly_wakano@yahoo.co.id.
}

\begin{abstract}
Abstrak: Perairan Desa Kampung Baru merupakan salah satu perairan yang ada di Pulau Banda Kabupaten Maluku Tengah yang memiliki kekayaan biota laut yang sangat melimpah. Kondisi substrat di perairan ini adalah berkarang, berbatu dan berpasir yang dikelilingi oleh lamun. Pada pesisir pantai Desa Kampung Baru ini banyak terdapat biotabiota laut, di antaranya adalah crustace, gastropoda, bivalvia, echinodermata, teripang, bintang laut dan lain-lain. Bulu babi merupakan salah satu biota yang sangat penting karena masyarakat pada Desa Kampung Baru memanfaatkan gonadnya untuk dikonsumsi sehari-hari. Keberadaan bulu babi pada ekosistem terumbu karang memberikan pengaruh yang signifikan terhadap keseimbangan ekologi. Tujuan dari penelitian ini adalah untuk mengetahui struktur komunitas Bulu Babi (Echinoidea) di Pesisir Pantai Desa Kampung Baru Kabupaten Maluku Tengah perlu dilakukan sehingga keberadaan bulu babi dapat diketahui sehingga keseimbangan terpantau dengan baik.Metode yang digunakan adalah transek linier kuadrat. Hasil penelitian menunjukkan keakekaragaman spesies bulu babi di pesisir pantai Desa kampung Baru Pulau Banda Maluku tengah sebesar 0.815, termasuk kategori rendah. Nilai Dominasi sebesar 0.512 yang artinya ada kecenderungan spesies mendominas. Nilai kepadatan sebesar 0.065 dan nilai sebaran sebesar 0.277 yang termasuk kategori seragam.
\end{abstract}

\section{Kata Kunci: Stuktur komunitas, Bulu Babi, Kampung baru, Pulau Banda}

Abstract: The waters of Kampung Baru Village are one of the waters in Banda Island, Central Maluku Regency, which has an abundance of marine life. The substrate conditions in these waters are rocky, rocky and sandy, surrounded by seagrass. On the coast of Kampung Baru Village, there are many marine biota, including crustaceans, gastropods, bivalves, echinoderms, sea cucumbers, starfish and others. Sea urchins are one of the most important biota because people in Kampung Baru Village use their gonads for daily consumption. The existence of sea urchins in coral reef ecosystems has a significant effect on the ecological balance. The purpose of this study was to determine the community structure of sea urchins in the coastal areas of Kampung Baru, Central Maluku Regency. It is necessary to do so so that the presence of sea urchins can be known 
so that the balance is well monitored. The method used is a quadratic linear transect. The results showed that the diversity of sea urchin species on the coast of the village of Kampung Baru, Banda Island, Central Maluku was 0.815, including the low category. The value of dominance is 0.512 , which means there is a tendency for species to dominate. The density value is 0.065 and the distribution value is 0.277 which is included in the uniform category.

\section{Keywords: Community Structure, Sea Urchins, Kampung Baru, Banda Island}

Provinsi Maluku dengan luas wilayah perairan sekitar 92,4\%, memiliki potensi sumber daya kelautan dan pesisir yang sangat menunjang pembangunan daerah. Perairan Maluku memiliki produksi perikanan laut sebesar 477.484 ton/tahun pada tahun 2012. Salah satu perairan di Maluku yang memiliki kekayaaan biota laut dan telah menjadi daya tarik bagi wisatawan mancanegara adalah perairan Pulau Banda.

Perairan Desa Kampung Baru merupakan salah satu perairan yang ada di Pulau Banda Kabupaten Maluku Tengah yang memiliki kekayaan biota laut yang sangat melimpah. Kondisi substrat di perairan ini adalah berkarang, berbatu dan berpasir yang dikelilingi oleh lamun. Pada pesisir pantai Desa Kampung Baru ini banyak terdapat biotabiota laut, di antaranya adalah crustace, gastropoda, bivalvia, echinodermata, teripang, bintang laut dan lain-lain. Bulu babi merupakan salah satu biota yang sangat penting karena masyarakat pada Desa Kampung Baru memanfaatkan gonadnya untuk dikonsumsi sehari-hari. Keberadaan bulu babi pada ekosistem terumbu karang memberikan pengaruh yang signifikan terhadap keseimbangan ekologi.

Keseimbangan populasi Diadema antillarum akan menjaga kesetimbangan populasi alga dan karang. Sedangkan kematian massal Diadema antillarum berdampak pada penurunan drastis tutupan karang, menurunnya kehadiran invertebrata yang biasanya menetap di wilayah ini. Selain itu, terumbu karang dapat didominasi oleh alga. Pada tahun 1995 ditemukan populasi Diadema antillarum yang sangat sedikit pemulihannya membutuhkan waktu lebih dari 10 tahun. Hilangnya induk Diadema antillarum menyebabkan jumlah larva juga sangat kurang. Meski telah mulai ada pemulihan Diadema, namun belum dapat diketahui apakah akan dapat mengembalikan terumbu karang yang hilang (Timotius, 2003)

Berdasarkan hal tersebut diatas maka penelitian tentang struktur komunitas Bulu Babi (Echinoidea) di Pesisir Pantai Desa Kampung Baru Kabupaten Maluku Tengah perlu dilakukan sehingga keberadaan bulu babi dapat diketahui sehingga keseimbangan terpantau dengan baik. 


\section{METODE PENELITIAN}

Penelitian ini merupakan penelitian observasi dan deskriptif kuantitatif, dengan menggunakan metode transek linier kuadrat (Suhardi, 1998). Penelitian ini dilakukan di pesisir pantai Desa Kampung Baru Pulau Banda Kabupaten Maluku Tengah (Gambar 1)

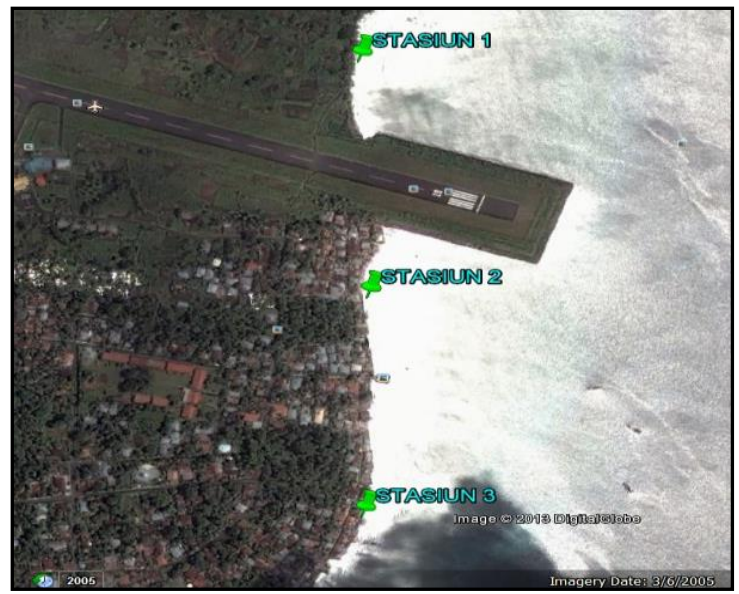

Gambar 1. Google Map Lokasi Penelitian

Alat-alat yang digunakan selama penelitian antara lain tali rafia, kamera, alat tulis menulis, toples sampel, kaos tangan, tali meteran, ember plastik, thermometer, refraknometer, $\mathrm{pH}$ meter, DO meter, meter rol, dan buku identifikasi bulu babi yang mengacu pada Clark dan Rowe (1971). Bahan-bahan yang digunakan selama penelitian antara lain bulu babi yang ditemukan, aquades dan formalin $4 \%$ untuk mengawetkan sampel bulu babi.

\section{Penentuan Stasiun}

Penentuan stasiun penelitian ditentukan berdasarkan panjang garis pantai Desa Kampung Baru yaitu \pm 900 m, maka:

1. Daerah pengambilan sampel dibagi menjadi 3 stasiun dengan jarak antar stasiun 225 m. Luas setiap stasiun adalah $1000 \mathrm{~m}^{2}$.

2. Pada setiap stasiun diletakan 3 garis transek dengan panjang $50 \mathrm{~m}$ secara tegak lurus garis pantai yang dimulai dari pasang tertinggi sampai surut terendah dengan jarak antar transek $40 \mathrm{~m}$.

3. Pada setiap transek diletakan 5 petak pengamatan secara berselang-seling dengan ukuran $1 \times 1 \mathrm{~m}^{2}$ dan jarak antar petak pengamatan $10 \mathrm{~m}$.

\section{Pengukuran Faktor Fisik Kimia}

Pengukuran parameter fisik kimia perairan dilakukan pada saat air pasang, dan faktor-faktor yang diukur meliputi:

1. Suhu. Suhu air diukur dengan menggunakan termometer air raksa yang dimasukkan ke dalam air \pm 10 menit kemudian dibaca skalanya.

2. Salinitas. Salinitas perairan diukur dengan menggunakan refraktometer yaitu dengan cara sampel air laut diambil dengan menggunakan pipet tetes. Pada permukaan dasar 
refraktometer yang telah dibersihkan diteteskan 1 tetes sampel air laut, tutup dan baca skala penunjuk angka.

3. $\mathrm{pH}$ air. $\mathrm{pH}$ diukur dengan menggunakan $\mathrm{pH}$ meter dengan cara memasukkan bagian elektroda ke dalam sampel air. Nilai $\mathrm{pH}$ dapat dibaca pada skala $\mathrm{pH}$ meter.

4. Oksigen terlarut (DO). DO (Dissolve Oxygen) diukur menggunakan DO meter dengan cara mencelupkan probe DO meter ke dalam air laut.

\section{Pengambilan Sampel}

1. Pengambilan sampel dilakukan pada saat air surut.

2. Bulu babi yang terdapat dalam petak pengamatan dihitung jumlah spesies dan jumlah individu untuk menentukan keankeragaman dan pola sebarannya jenisnya.

3. Bulu babi yang telah dihitung diambil satu individu per spesies yang ditemukan untuk identifikasi.

4. Pengambilan individu contoh untuk identifikasi dilakukan berdasarkan bentuk morfologi.

5. Bulu babi direndam dalam formalin $4 \%$

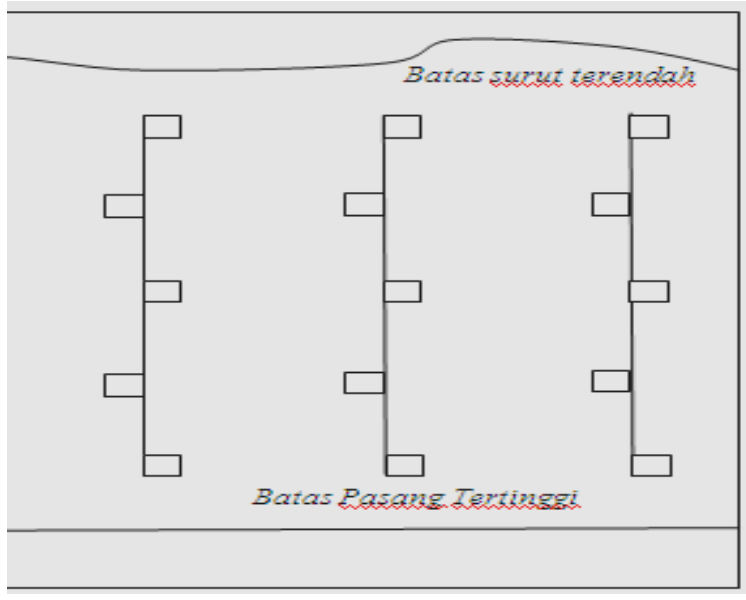

Gambar 2. Plotting Pengambilan Sampel

Untuk mengetahui nilai indeks keanekaragaman, pola sebaran dan indeks dominansi dari Bulu babi (echinoedea) menggunakan rumus menurut (Soegianto, 1994). Keragaman bulu babi dapat dihitung dengan menggunakan rumus indeks diversitas Shannon-Wiener (Odum, 1993) sebagai berikut:

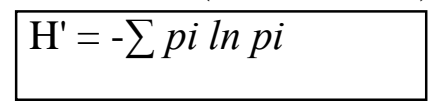

Dimana : $\mathrm{H}^{\prime}=$ indeks keanekaragaman Shanon- Wienner

$\mathrm{Pi}=$ ni/N

$\mathrm{ni}=$ jumlah individu spesies ke-i

$\mathrm{N}=$ total jumlah individu

$l n=$ logaritma nature

Untuk mengetahui indeks dominasi bulu babi dapat menggunakan rumus sebagai berikut: 


$$
\mathrm{D}=(\mathrm{Pi})^{2}
$$

Dimana:

$\mathrm{D}=$ Indeks Dominasi Simson

$\mathrm{Pi}=\mathrm{ni} / \mathrm{N}$

$\mathrm{ni}=$ Jumlah Individu setiap Spesies

$\mathrm{N}$ = Total individu seluruh spesies

Dengan Kategori:

Jika $\mathrm{D}$ mendekati $0(\mathrm{D} \leq 0,5)$ tidak ada spesies yang mendominasi

Jika $\mathrm{D}$ medekati $1(\mathrm{D} \geq 0,5)$ ada jenis yang mendominasi

Kepadatan (Brower. J. E. et al. 1990)

$$
\mathrm{Di}=\mathrm{ni} / \mathrm{A}
$$

Dimna:

$\mathrm{Di}=$ Kepadatan untuk spesies ke $\mathrm{i}$

$\mathrm{ni}=$ Jumlah individu setiap spesies

$\mathrm{A}=$ Luas total habitat yang disamping $\left(\mathrm{ind} / \mathrm{m}^{2}\right)$

Pola penyebaran bulu babi dalam penelitian ini ditentukan dengan menggunakan Indeks Morisita. Indeks ini tidak dipengaruhi oleh luas stasiun pengambilan sampel dan sangat baik untuk membandingkan pola pemencaran populasi (Brower et al, 1990). Rumus dipergunakan adalah:

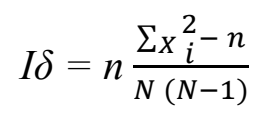

Dimana:

I $\quad=$ Indeks Distribusi Morisita

$\mathrm{N} \quad=$ Jumlah Seluruh individu dalam total $\mathrm{n}$

$\mathrm{n} \quad=$ Jumlah seluruh stasiun pengambilan sampel

$\sum \mathrm{x}_{\mathrm{i}}{ }^{2} \quad=$ Kuadrat jumlah spesies bulu babi jenis $-\mathrm{i}$ per stasiun

Nilai indeks Morisita yang diperoleh di interpretasikan sebagai berikut:

I $\delta<1$, pemencaran individu cenderung seragam

I $\delta=1$, pemencaran individu bersifat acak

I $\delta>1$, pemencaran individu cenderung berkelompok

Keterangan:

$n i=$ jumlah Individu jenis ke- $\mathrm{i}$

$\mathrm{N}=$ jumlah total individu 


\section{HASIL DAN PEMBASAN}

\section{Komposisi Jenis Bulu Babi di Pesisir pantai Desa Kampung Baru Pulau Banda}

Dari penelitian yang dilakukan maka dapat dijelaskan bahwa komposisi jenis bulu babi adalah sebagai berikut.

Tabel 1 Komposisi Jenis Bulu Babi Di perairan Pantai Desa Kampung Baru Pulau Banda

\begin{tabular}{|c|c|c|c|c|}
\hline Stasiun & Tipe Substrat & Famili & Spesies & $\Sigma$ Individu \\
\hline \multirow[t]{2}{*}{$\mathbf{I}$} & \multirow{2}{*}{$\begin{array}{l}\text { Pasir berlumpur, } \\
\text { pecahan karang dan } \\
\text { berbatu }\end{array}$} & Laganidae & Staphecinus mirabilis & 154 \\
\hline & & Diametidae & Diadema setosum & 17 \\
\hline \multirow[t]{3}{*}{ II } & \multirow[t]{3}{*}{ Berpasir } & \multirow[t]{2}{*}{ Diametidae } & Diadema setosum & 191 \\
\hline & & & Tripneustes gratilla & 28 \\
\hline & & Laganidae & Staphecinus mirabilis & 6 \\
\hline \multirow[t]{2}{*}{ III } & \multirow{2}{*}{$\begin{array}{l}\text { Berpasir dan pasir } \\
\text { berlumpur }\end{array}$} & \multirow[t]{2}{*}{ Diametidae } & Diadema setosum & 195 \\
\hline & & & Tripneustes gratilla & 17 \\
\hline \multicolumn{4}{|l|}{$\sum$} & 608 \\
\hline
\end{tabular}

Dari tabel tersebut diatas dapat dijelaskan bahwa pada stasiun I dengan tipe substrat pasir berlumpur, berbatu dan pecahan karang ditemukan dua jenis bulu babi yaitu Staphecinus mirabilis sebanyak154 individu dan Diadema setosum sebanyak 17 individu. Pada stasiun II dengan tipe substrat berpasir ditemukan 3 jenis bulu babi yaitu Diadema setosum sebanyak 191 individu, Tripnesutes gratilla sebanyak 28 individu dan Staphecinus mirabilis sebanyak 6 individu. Sedangkan pada stasiun III dengan tipe substrat berpasir dan pasir berlumpur ditemukan dua jenis bulu babi yaitu Diadema setosum sebanyak 195 individu dan Tripnesutes gratilla sebanyak 17 individu. Jadi jumlah keseluruhan spesies bulu babi yang ditemukan di Pulau Banda ada tiga spesies yaitu Diadema setosum, Tripnesutes gratilla, dan Staphecinus mirabilis dengan total individu 608 individu. Adapun tiga jenis tersebut dapat dilihat pada gambar 1 berikut.
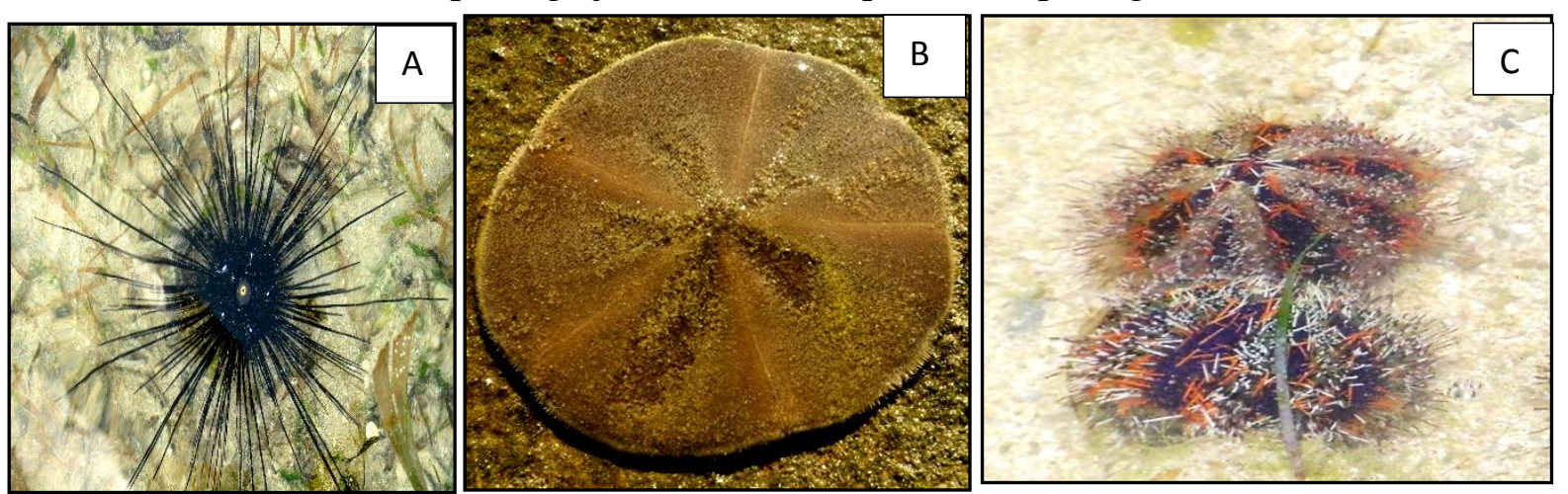

Gambar 4.1. Jenis-jenis Bulu Babi di Perairan Desa Kampung Baru Pulau Banda yang ditemukan (A) Diadema setosum, (B) Staphecinus mirabilis dan (C) Tripneustes gratilla.

Menurut Aziz (1996) bahwa Deadema setosum menyebar hampir pada semua habitat, yaitu merata pada zona rataan pasir, karang lamun, lumpur, dan daerah tubir. Pada pesisir pantai Desa Kampung Baru pulau Banda ditemukan adanya ekosistem padang 
lamun. Jenis lamun yang ditemukan pada lokasi penelitian ini adalah Enhalus acoroides dan Thalassia hempricii.

Selain itu, Diadema setosum ditemukan dalam jumlah banyak juga disebabkan karena Diadema setosum mempunyai kaki tabung yang panjang untuk digerakkan pada beberapa tipe substrat. Berbeda dengan kedua spesies lainnya, Diadema setosum memiliki kaki tabung serta duri yang lebih panjang sehingga mampu hidup dan bergerak serta melakukan aktivitas hariannya pada tipe substrat (Suwignyo et al.2005)

Spesies Staphecinus mirabilis pada penelitian ini, hanya ditemukan pada stasiun I dan II, tidak ditemukan pada stasiun III. Hal ini disebabkan karena tipe substrat yang cenderung lunak pada stasiun I sehingga menyulitkan spesies ini untuk beradaptasi maupun untuk mencari makan pada stasiun ini. Rendahnya nilai Staphecinus mirabilis juga disebabkan karena spesies ini hidup membenamkan diri di dalam pasir sehingga sulit ditemukan. Menurut Sugiarto (2007), anggota Echinoidea biasanya hidup membenamkan diri dipasir atau dicelah bebatuan pantai. Bulu babi Tripneustes gratilla dalam penelitian ini diperoleh dalam jumlah yang sangat sedikit. Hal ini disebabkan karena bulu babi jenis ini banyak diambil oleh masyarakat setempat untuk di konsumsi sebagai bahan makanan karena memiliki nilai gizi yang tinggi dan dimanfaatkan nelayan sebagai sumber penghasilan. Pertumbuhan biota laut di daerah pasang surut sangat tinggi, disebabkan karena daerah ini merupakan tempat hidup, tempat berlindung, dan tempat mencari makan. (Aziz, 1993)

\section{Indeks Ekologi Bulu Babi di Pesisir Pantai Desa Kampung Baru Pulau Banda Maluku Tengah}

Berdasarkan analisis data yang dilakukan tentang indeks ekologi, maka dapat disaji seperti pada tabel berikut.

Tabel 2 Beberapa Indeks ekologi Bulu Babi Di pesisir pantai Desa Kampung Baru Pulau Banda

\begin{tabular}{|lll|}
\hline Indeks Ekologi & Nilai & Ketegori \\
\hline Keanekaragaman $\left(\mathrm{H}^{\prime}\right)$ & $\mathbf{0 . 8 1 5}$ & Rendah \\
\hline Dominasi ( D ) & $\mathbf{0 . 5 1 2}$ & Cenderung ada spesies yang mendominasi \\
\hline Kepadatan ( Di ) & $\mathbf{0 . 0 6 5}$ & \\
\hline Pola Distribusi $(I \delta)$ & $\mathbf{0 , 2 7 7}$ & Seragam \\
\hline
\end{tabular}

Dari tabel di atas dapat dijelaskan bahwa nilai keakekaragaman sebesar 0.815 , termasuk kategori rendah. Nilai Dominasi sebesar 0.512 yang artinya ada kecenderungan spesies mendominas. Nilai kepadatan sebesar 0.065 dan nilai sebaran sebesar 0.277 yang termasuk kategori seragam.

Tinggi rendahnya keanekaragaman spesies ditentukan oleh jumlah spesies dan jumlah keseluruhan individu. Menurut Kaswadji, 1974, apabila indeks keragaman kurang dari 1, maka spesies tersebut digolongkan memiliki keragaman yang rendah, namun nilai keragaman spesies lebih dari 1, hal tersebut menunjukkan keragaman spesies 
relatif sedang, dan apabila nilai keragaman spesies mencapai 4, maka keragaman spesies tinggi.

Rendahnya nilai keanekaragaman dalam penelitian ini disebabkan karena adanya aktivitas manusia disekitar lokasi penelitian tersebut seperti pengambilan pasir, biota laut dan aktivitas kapal dan perahu boat. Hal ini sesuai dengan pendapat Odum (1994) yang mengemukakan bahwa meningkatnya tingkat stress atau tekanan di lingkungan seperti adaptasi menyebabkan berkurangnya keanekaragaman spesies. Effendi (2003) menyatakan bahwa tinggi rendahnya keragaman suatu spesies dari suatu perairan dipengaruhi oleh banyak faktor antara lain tipe substrat, stabilitas lingkungan dan panjang rantai makanan. Michael (1994) menambahkan bahwa tinggi rendahnya keanekragaman spesies ditentukan oleh jumlah spesies dan jumlah keseluruhan spesies.

Hasil penelitian ini sama dengan hasil penelitian Julianti (2012) yang melakukan penelitian di Perairan Teluk Ambon Bagian Dalam menemukan bahwa keragaman bulu babi di perairan tersebut tergolong rendah yaitu kurang dari 1. Supono dan Arbi (2010), menyatakan bahwa tinggi rendahnya nilai keragaman jenis dapat disebabkan oleh berbagai faktor, antara lain jumlah jenis dan individu, homogenitas substrat dan kondisi tiga ekosistem penting di daerah pesisir (padang lamun, terumbu karang dan hutan mangrove). Sugiarto dan Supardi (1995) bahwa tinggi rendahnya keanekaragaman dipengaruhi oleh banyak faktor, salah satunya adalah jumlah dan jenis kualitas lingkungan. (Kaswadji, 1974) menambahkan bahwa semakin banyak jumlah spesies dengan proporsi yang seimbang menunjukkan keanekaragaman semakin tinggi. Menurut Soegianto (1994), suatu komunitas dikatakan mempunyai keanekaragaman jenis tinggi jika komunitas itu disusun oleh banyak jenis dengan kelimpahan jenis yang sama atau hampir sama. Sebaliknya jika komunitas itu disusun oleh sangat sedikit jenis dan jika hanya sedikit jenis yang dominan maka keanekaragaman jenisnya rendah.

Keanekaragaman yang tinggi menunjukkan bahwa suatu komunitas memiliki kompleksitas tinggi karena dalam komunitas itu terjadi interaksi jenis yang tinggi pula. Jadi dalam suatu komunitas yang mempunyai keanekaragaman jenis tinggi akan terjadi interaksi jenis yang melibatkan transfer energi (jaring-jaring makanan), predasi, kompetisi, dan pembagian relung yang secara teoritis lebih kompleks. Hasil analisis pola sebaran masing-masing spesies pada ketiga stasiun penelitian menunjukkan bahwa pada pesisir pantai Desa Kampung Baru Pulau Banda Kabupaten Maluku Tengah secara keseluruhan bulu babi memiliki pola sebaran seragam. Menurut Barus (1990) menyatakan pola penyebaran spesies di tentukan dengan menggunakan indikator sebagai berikut;jika I < 1 maka pola penyebaran seragam, jika I >1 maka pola penyebarannya kelompok, jika I = 1 maka pola penyebarannya acak.

Pola penyebaran seragam yang diperoleh pada penelitian ini disebabkan karena adanya variasi faktor lingkungan sehingga suatu spesies cenderung untuk mencari daerah dengan faktor lingkungan yang sesuai untuk pertumbuhannya dan adanya kecenderungan 
seragam berdasarkan umur, melindungi diri dan tidak ada persaingan. Hal ini menunjukkan bahwa masing-masing spesies memiliki kisaran toleransi (suhu dan salinitas) yang sama terhadap kondisi lingkungan yang sama. Odum (1998), menyatakan bahwa pola penyebaran seragam dapat terjadi karena ada persaingan yang kuat antara spesies sehingga mendorong terjadinya pembagian ruang yang sama. Aziz (1994) mengungkapkan bahwa pola penyebaran menggambarkan posisi suatu spesies berdasarkan pergerakan dan perpindahannya. Distribusi dari suatu individu mungkin dibatasi oleh faktor perilaku pemilihan habitatnya. Selain itu, diduga terdapat faktor adaptasi lain yang mempengaruhi hubungan yang tidak signifikan, dan adanya tingkat stress fisioligis dan ketersediaan makanan.

\section{KESIMPULAN}

Berdasarkan hasil penelitian yang telah dilakukan dapat disimpulkan bahwa : keakekaragaman spesies bulu babi di pesisir pantai Desa kampung Baru Pulau Banda Maluku tengah sebesar 0.815, termasuk kategori rendah. Nilai Dominasi sebesar 0.512 yang artinya ada kecenderungan spesies mendominas. Nilai kepadatan sebesar 0.065 dan nilai sebaran sebesar 0.277 yang termasuk kategori seragam.

\section{DAFTAR PUSTAKA}

Aziz, A. (1993). Beberapa catatan tentang perikanan bulu babi. Oseana 18(2): 65-75

Aziz A. (1994). Tingkah laku bulu babi di padang lamun. Oseana 19(4): 35-43.

Barus, T. A. (1990). Pengantar Limnologi Studi Tentang Ekosistem Daratan. USU Press. Medan.

Brower, J., J. Zar, C.V. Ende, K. Kane. (1990). Field and laboratory methods for general ecology. Edisi ke-3. Wm. C. Brown Publishers. America.

Clark, AM and FEW Rowe. (1971). Monograph of Shallow-water Indo-West Pacific Echinoderms. No. 690. British Museum. pp. 238

Effendi, H. (2003). Telaah Kualitas Air Bagi Pengelolaan Sumberdaya Lingkungan Perairan. Kanisius. Yogyakarta

Kaswadji, R.F.et al. (1974). Produktifitas Primer dan Laju PertumbuhanFitoplankton di Perairan Pantai Bekasi. Jurnal. Ilmu-Ilmu Perairan danPerikanan.

Michael, P. (1995). Metode Ekologi untuk Penyelidikan Ladangdan Laboratorium. UI Press. Jakarta.

Odum, E.P. (1993). Dasar-dasar Ekologi. Terjemahan Tjahjono Samingan. Edisi Ketiga. Gadjah Mada University Press. Yogyakarta.

Odum, E. P. (1994). Dasar-Dasar Ekologi. Gadjah Mada University Press. Yogyakarta. Sugiyono. (2001). Metode Penelitian Bisnis. Cetakan Ketiga, Alfabeta, Bandung 
Supono, dan U. Y. Arbi. (2010). Struktur Komunitas Ekinodermata di Padang Lamun Perairan Kema, Sulawesi Utara. Oseanologi dan Limnologi di Indonesia. 36(3): 329-341.

Suwignyo S, Widigdo B, Wardiatno Y, Krisanti M. (2005). Avertebrata Air Jilid 2. Penebar Swadaya. Jakarta.

Sugiarto. (2017). Fauna ekhinodermata padang lamun di pantai Lombok selatan. Dalam: W. Kiswara, M.K. Moosa dan M. Hutomo (eds.), Struktur Komunitas Biologi Padang Lamun di Pantai Selatan Lombok dan Kkondisi Lingkungannya. Puslitbang Oseanologi - LIPI, Jakarta: 52 - 63.

Sugiarto, H. dan Supardi. (1995). Beberapa Catatan tentang Bulu Babi Marga Diadema. Oseana. 20 (4): $35-41$.

Timotius, S. (2003). Biologi Terumbu Karang [online]. www.terangi.or.id/ publications/pdf/ biologikarang.pdf. 22 April 2019. 